\title{
Study of Recall in Reading Skill with Relationship of Prior Knowledge-Researching Significative Intergrupal Differencies
}

\author{
María del Carmen Gil del Pino ${ }^{1}$, Vicente J. Llorent García ${ }^{1} \&$ Juan Carlos Varo Millán ${ }^{1}$ \\ ${ }^{1}$ University of Cordoba, Spain \\ Correspondence: Vicente J. Llorent García, Dpto. de Educación. Fac. de CC. de la Educación Avda. S. Alberto \\ Magno s/n, Universidad de Córdoba, 14004 Córdoba, Spain. Tel: 34-957-212-585. E-mail: vjllorent@uco.es
}

Received: March 15, 2013 Accepted: April 19, 2013 Online Published: November 25, 2013

doi:10.5539/ies.v6n12p15 URL: http://dx.doi.org/10.5539/ies.v6n12p15

\begin{abstract}
In this paper we try to assess whether there are differences in a group when their members try to remember the content of a text, and if this fact affects the learning levels through an experimental methodology with a design of two groups only with posttest to assess the readers' free recall after reading a text. We found firstly interindividual and intergroup differences in recall of textual material. And secondly text comprehension and therefore the memory of the reading depend largely on reader's inferences. In this paper we propose a specific intervention in order to prepare students for a better understanding of the text read, using a simple methodology to apply with materials easy to prepare.
\end{abstract}

Keywords: recall, reading comprehension, learning, education

\section{Introduction and Problem}

In a free-recall process, the reader organizes the text's information by memory where the words are positioned in a special order so they can be remembered, so in the reading process the reader organizes the information in the best way of enhancing recall. Thus, the process of clustering words in groups with similar meaning makes easier the recall (Watkins \& Gardiner, 1979; Hall \& Gathercole, 2011)

Nevertheless, the efficiency of memory recall can be increased by making inferences from our personal background, our previous knowledge about the issue, making inferences and assumptions about how to interpret and process information from the text (Anderson \& Pearson, 1984).

Studies have shown that subjects with developed skills have a deeper understanding and matured of the act of reading (Baker, 1991; Ehren, 2005; Garner 1988; Mason, 2004). For example, Baker (1991) recorded that they see reading as a process of 'making sense' to read an entire text, while the less skilled who define it as a simple process of decoding or, in terms of Gagné (1985), recoding.

Unlike the simple act of reading, understanding does not involve performing a particular action. Reading comprehension is a characteristic related to result of having performed certain actions in an effective way. (Ryle, 1949; Wigfield et al., 2008).

Read more than just a mechanical act decryption of graphic signs is, above all, an act of reasoning, symbolization, imagination. What matters is what they convey interpret the printed letters, build a new meaning in the mind from the signs. It follows that reading is a complex process given the variety of cognitive operations, requiring pragmatic and sociocultural. Furthermore, the resulting enjoyment written text, coming from both the signifier and the signified, is not immediate (Sotozaki \& Hatin, 2011).

Thus in order to better understand texts better, readers need to turn their semantic contents into mental pictures (Tomlinson, 1997; Hobbs, 2001). So, comprehending a text involves the ability to do things in different psychological areas (Barry \& Lazarte, 1998), and free recall can be proposed as a good assessment technique for comprehension reading tests to measure comprehension (Kintsch, 1998).

Thus, to keep in memory a text, we use visual memory through visual recognition-checker and the settings written words on it. This visual processing of written text is complemented by associating phonological components which can then be decoded (Bravo, 2003), and the imagery produced in the mind during reading (Brewer, 1988). 
When children in the early years of primary education, acquire basic literacy skills, teachers emphasize longer to learn to read and pass it on to read to learn. Certainly, in the last stages of Elementary as in Secondary Education, it highlights the emphasis on reading as the key to student learning.

However, some studies show that many adolescents have significant difficulties when reading for information or to understand instructions. Unfortunately, there is growing evidence that students do not read effectively, that their understanding is minimal and literal. Therefore, educational psychologists continue to show great interest in this topic and research currently generate a huge amount of literature.

Pearson et al. (1992) have shown that proficient readers possess definite characteristics, among others, the use of prior knowledge to make sense of reading and assessing their understanding during the reading process. Meanwhile Kourilsky and Wittrock (1987) found that using verbal elaborations first, followed by imaging, significantly increased economic understanding in high school students. Likewise, Jimenez, Garcia, and Pearson (1996) identified twenty-two different reading strategies in a study with bilingual children who were identified as successful readers.

Nevertheless, prior knowledge on the subject of reading is paramount. Well if you are familiar with the content, is likely to attribute a meaning. If this does not happen before a properly drafted text, may be due on the one hand, the reader has no previous knowledge of its content, on the other that, despite having the prior knowledge, the text itself does not provide any data leads the reader to it, and finally, although the reader apply some prior knowledge and thus build an interpretation, this is not intended to match the content of the text (Baker \& Brown, 1984; Gilabert, Martínez, \& Vidal-Abarca, 2005; Marmolejo-Ramos et al., 2009).

Identify therefore what elements influencing reading comprehension depend, in large measure, on the manner in which delimits conceptualized and functionality. Brown, Campione, and Day (1981) propose a model of word processing (Tetrahedron Model) amounts to a classification of studies being done on reading comprehension, divided into four groups of variables that can determine the course and efficiency of reading comprehension: 1) the characteristics of the reader, 2) text features, 3) the goals of the reader, and 4) reading strategies. But in this paper, we focus on assessing free recall that readers from different ages and groups have from reading a text.

This study is motivated by the frequency in which appear in the many different schools, students with a high rate of school failure because, among other reasons, they do not understand what they read for lack of reading comprehension skills (Vargas \& Arbeláez, 2001).

\section{Method}

\subsection{Hypothesis}

Exist both, individual differences as intergroup differences which can be statistically significant in the remembering process to textual material

\subsection{Sampling Procedures}

We have developed as a research tool, a short two-leaf booklet that we applied after. The first contained a space for personal data and text subject 'Los superpetroleros' (Supertankers). The second was blank but had written on the top the following: "After reading, please, try to write everything you remember without reading it again. You have ten minutes time. You can use both sides of this sheet".

It was decided to apply the instrument to students at a Secondary School in Cordoba (Spain) just because we had easy access due to we knew a professor of Geography and History. The activity was held at 8.15 in the morning of two consecutive days (specifically, on $4^{\text {th }}$ and $5^{\text {th }}$ of April, 2010). After the presentation and greeting students, it was given the two-leaf booklet and it was told them they had ten minutes to read the text. After the appointed time, the subjects were distracted with a conversation referring to the Easter holidays, which were already very close. When the time was run out, they were told they already could start writing everything they could remember from the reading. And after ten minutes, they were asked to deliver the booklet.

Then we proceeded to the analysis of the memory by using the scheme presented below:

First scenario: Presentation (2 points)

$>$ Problem Statement: possible oil spill (1 point)

$>$ An allusion to the importance and consequences of the spill consequences: pollution, damage to nature (1 point)

Second scenario: Causes ( 3 points)

$>$ An allusion to the causes of the sinking of supertankers are two (1 point)

$>$ An allusion to a cause is the low power (1 point) 
An allusion to another cause is the limited maneuverability (1 point)

Third scenario: solutions (5 points)

$>$ Presence of a sentence that says that you cannot do without the Supertankers (1 point)

$>$ Presence of a sentence in which it is said that there are three possible solutions to the problem (1 point)

$>$ Presence of a sentence in which it is said that the training of officers in the conduct of the ship is a first solution (1 point)

$>$ Presence of a sentence in which it is said that the construction of ships is a second best solution (1 point)

$>$ Presence of a sentence in which it is said that the installation of large control stations to guide supertankers off the coast is a third solution (1 point)

After obtaining the data, we used the SPSS software (version 18).

We present here an experimental methodology with a design of two groups only with posttest to assess the readers' free recall after reading a text.

With a process of selection and randomization of readers which are from different age and different groups.

\subsection{Participants}

Fifty five students participated in the study the $29^{\text {th }}$ January 2010 , from $1^{\text {st }}$ year of Compulsory Secondary Education in Spain (ESO) -born mostly in 1998 and, therefore, with twelve or thirteen years old, and 26 students from $1^{\text {st }}$ year of Baccalaureate ( $1^{\text {st }}$ year of College in Spain) -born mostly in 1994 and, therefore, with sixteen or seventeen years old. They are students of Maimonides Secondary School in Córdoba (Spain), School of secondary education level located in the city center with a population of 1.300 students spread between Secondary Education, College, Vocational Training and Initial Professional Qualification Programmes (PCPIs).

\section{Presentation of Data and Results}

In Table 1 (ESO students) and Table 2 (high school students) we can find the scores for each subject in each stage according to the score assigned to each one. For example, in Table 1 we find that the subject 1 gets 1 point of 2 for scenario 1, which is because this student could only recalled one of the elements from content of this part of the text. While the subject 8 and the subject 19 both do not answer due to not remember anything, this could occur possibly for reading problems, which prevent them from remembering the content due to not understand in the reading process.

The tables also show the number of inferences made by the reader that we compare with numerical data of the points obtained from the information remembered, to see how this inference provided by the reader affects to the free recall.

We believe therein lies the main element of interpersonal differences among readers: the inference provided to understand the text.

As understanding of the reading is one of the most complex human cognitive activities, which consist of the construction in the episodic memory just a mental representation of the text, not as an aggregate of individual pieces of information, but as a coherent structure (Lorch \& van den Broek, 1997; Molinari-Marotto, 1998).

So while the reader reads, it needs to do personal inferences to build a coherent representation of the text content, and facilitate their understanding and therefore better recall (van den Broek, 1994).

At this point, we have to define the concept of interindividual differences we use in this paper; we will say that it is the differences that readers present when they remember the content of a text, according to the content understanding. Which we think is happening to the extent that their representation of the content is coherent based on the consistency of representation being built with the inferences they generate. This generation refers to the inclusion of information previously known by the reader to the mental representation of the text content.

So we can understand that links are established between different parts in the text, that are not explicitly stated, so when it is linked the content of the text with elements of prior knowledge, they become part of the reader's mental representation, which will help you remember more or less of content, depending on the consistency of their inferences. 
Table 1. Student rating of $1^{\text {st }}$ year of ESO

\begin{tabular}{|c|c|c|c|c|c|c|c|}
\hline & Scenario 1 & Scenario 2 & Scenario 3 & Total & Inf. Corr. & Infer. Incor. & Total \\
\hline Subject 1 & 1 & 1 & 5 & 7 & 3 & 1 & 4 \\
\hline Subject 2 & 1 & 1 & 3 & 5 & 1 & 1 & 2 \\
\hline Subject 3 & 1 & 1 & 2 & 4 & 2 & & 2 \\
\hline Subject 4 & 1 & & 3 & 4 & 4 & & 4 \\
\hline Subject 5 & 2 & & 1 & 3 & 1 & & 1 \\
\hline Subject 6 & 1 & & & 1 & & & 0 \\
\hline Subject 7 & 1 & & 1 & 2 & & & 0 \\
\hline Subject 8 & NA & & & & & & \\
\hline Subject 9 & 1 & & & 1 & 2 & & 2 \\
\hline Subject 10 & 1 & & 5 & 6 & 2 & & 2 \\
\hline Subject 11 & 1 & & & 1 & 2 & & 2 \\
\hline Subject 12 & & & & $\mathbf{0}$ & & & 0 \\
\hline Subject 13 & 1 & & & 1 & & & 0 \\
\hline Subject 14 & & & & $\mathbf{0}$ & & & 0 \\
\hline Subject 15 & & & & $\mathbf{0}$ & & & 0 \\
\hline Subject 16 & 1 & & & 1 & & & 0 \\
\hline Subject 17 & 1 & & & 1 & 1 & & 1 \\
\hline Subject 18 & & & 1 & 1 & 1 & & 1 \\
\hline Subject 19 & NA & & & & & & \\
\hline Subject 20 & & 1 & 1 & 2 & 1 & & 1 \\
\hline Subject 21 & & & & $\mathbf{0}$ & & & 0 \\
\hline Subject 22 & 1 & & & 1 & & & 0 \\
\hline Subject 23 & 1 & 2 & 2 & 5 & 1 & & 1 \\
\hline Subject 24 & 1 & & & 1 & & & $\mathbf{0}$ \\
\hline Subject 25 & & & 1 & 1 & 1 & & 1 \\
\hline Subject 26 & 1 & & 3 & 4 & 1 & 1 & 2 \\
\hline Subject 27 & 1 & 1 & 2 & 4 & 2 & 1 & 3 \\
\hline Subject 28 & 2 & & 1 & 3 & & & 0 \\
\hline Subject 29 & 1 & & 3 & 4 & 1 & & 1 \\
\hline TOTAL & 22 & 7 & 34 & 63 & 26 & 4 & 29 \\
\hline
\end{tabular}

Own made table. 
Table 2. Student rating of 1st year of Baccalaureate

\begin{tabular}{|c|c|c|c|c|c|c|c|}
\hline & Scenario 1 & Scenario 2 & Scenario 3 & Total & Inf. Corr. & Infer. Incor. & \\
\hline Subject 1 & 2 & & 3 & 5 & & & $\mathbf{0}$ \\
\hline Subject 2 & 2 & 2 & 4 & 8 & & & $\mathbf{0}$ \\
\hline Subject 3 & 2 & 2 & 3 & 7 & 1 & & 1 \\
\hline Subject 4 & 2 & 1 & & 3 & 1 & & 1 \\
\hline Subject 5 & 2 & & 4 & 6 & 2 & & 2 \\
\hline Subject 6 & 2 & 2 & 5 & 9 & 2 & & 2 \\
\hline Subject 7 & 1 & & 3 & 4 & & 1 & 1 \\
\hline Subject 8 & 1 & & 3 & 4 & 2 & & 2 \\
\hline Subject 9 & 2 & & 4 & 6 & 2 & & 2 \\
\hline Subject 10 & 2 & 1 & 5 & 8 & 1 & & 1 \\
\hline Subject 11 & 1 & & 1 & 2 & 1 & 2 & 3 \\
\hline Subject 12 & 2 & & 1 & 3 & 2 & 1 & 3 \\
\hline Subject 13 & 2 & & 4 & 6 & 1 & & 1 \\
\hline Subject 14 & 2 & 2 & 4 & 8 & 4 & 1 & 5 \\
\hline Subject 15 & 1 & & 4 & 5 & 3 & & 3 \\
\hline Subject 16 & 2 & & 2 & 4 & 3 & & 3 \\
\hline Subject 17 & 2 & 2 & 3 & 7 & 2 & & 2 \\
\hline Subject 18 & 1 & 1 & 3 & 5 & 1 & & 1 \\
\hline Subject 19 & 1 & 1 & 1 & 3 & 2 & 1 & 3 \\
\hline Subject 20 & 2 & 1 & 4 & 7 & 3 & & 3 \\
\hline Subject 21 & & & 4 & 4 & 1 & & 1 \\
\hline Subject 22 & 2 & & 4 & 6 & 1 & & 1 \\
\hline Subject 23 & 1 & & 2 & 3 & 3 & & 3 \\
\hline Subject 24 & 2 & 1 & 3 & 6 & 1 & & 1 \\
\hline Subject 25 & 2 & 1 & 4 & 7 & 2 & & 2 \\
\hline Subject 26 & 1 & 1 & 4 & 6 & 2 & & 2 \\
\hline TOTAL & 42 & 18 & 82 & 142 & 43 & 6 & 49 \\
\hline
\end{tabular}

Own made table.

With these data, we proceeded to perform statistical calculations through SPSS tool, obtaining the following:

Table 3. Group statistics

\begin{tabular}{cccccc}
\hline & Course & $\mathrm{N}$ & Mean & Standard Deviation & Standard error of the mean \\
\hline \multirow{2}{*}{ Scenario1 } & .00 & 29 & .7586 & .57664 & .10708 \\
& 1.00 & 26 & 1.6154 & .57110 & .11200 \\
\hline \multirow{2}{*}{ Scenario2 } & .00 & 29 & .2414 & .51096 & .09488 \\
& 1.00 & 25 & .7200 & .79162 & .15832 \\
\hline \multirow{2}{*}{ Scenario3 } & .00 & 29 & 1.1724 & 1.51349 & .28105 \\
& 1.00 & 26 & 3.1538 & 1.28662 & .25233 \\
\hline \multirow{2}{*}{ Total } & .00 & 29 & 2.1724 & 2.01900 & .37492 \\
& 1.00 & 26 & 5.4615 & 1.88108 & .36891 \\
\hline
\end{tabular}


Table obtained through SPSS (version 18)

Course column:

- .00 corresponds to $1^{\text {st }}$ year of ESO.

- and 1.00 to $1^{\text {st }}$ year of Baccalaureate.

Assuming normality and equal variance, significant differences in all scenarios and total scores for the high school group ever. Specifically, the $t$ test in scenario 1 showed a significant difference $t(53)=-5.52, p=0.000$, in scenario 3 also found a significant difference in favor of the high school group $t(53)=-5.19, p=.000$. Of course, the total scores on the three scenarios shows a significant difference in the same sense as the above $t$ (53) $=-6.22$, with $p=.000$.

As the $2^{\text {nd }}$ scenario, Levene's test for equality of variance shows that in this case there is no such equality $F(1.54)$ $=10.782, p=.002$. Thus, we applied the Welch test also yields a significant difference $F(1.54)=6724, p=.013$.

In relation to interindividual differences as the variability in the remembering process to textual material, we propose that interindividual differences can be used as a source of information to elaborate new tools to try to improve the text recall process of each individual. So, it has been necessary to find measures to report on the differences between the scores, this is, the concentration or dispersion of the subject around the average, or what is the same, the homogeneity or heterogeneity of the values obtained (Note 1). To this we turn to use the measure of dispersion or variability most used: the standard deviation. After doing the calculations, we obtain the high values shown in Table 3 (Note 2).

The data show that understanding is a very important factor that may be affecting significantly the learning process, especially that of some individual students.

And as regards the inferences made by the students, we note that these are generally very low and increase with age (the sum is 29 in $1^{\text {st }}$ year of ESO and 49 in $1^{\text {st }}$ year of Baccalaureate). As expected, inferences about the reading material is a skill that good readers tend to be absent in the less skilled. Nevertheless, it is clear that understand a text is not just a matter of quantity of inferences.

\section{Discussion and Conclusions}

The study verifies the research hypotheses posed. Certainly, there are interindividual and intergroup differences in recall of textual material.

So, as we have already mentioned, text comprehension and therefore the memory of the reading depend largely on reader's inferences. In our study the text does not present any list exhaustively with the information required to understand it. So, the understanding depends on the inferred information by reader.

To summarize a text, the reader has to select which parts are most important, condensing the material and replace higher-order concepts and integrate what you read in a coherent and accurate (Pressley \& Schneider, 1997; Taboada \& Guthrie, 2006).

To which we can add that the ability to recognize text in visual-orthographic learning positively influence the reader (Pino, 2002).

Moreover, it should be mentioned that since Storch and Whitehurst (2002) in a longitudinal study from infant education stage through the fourth year of primary education, and found that reading ability was affected by the level of phonological awareness and the who had prior knowledge about the text.

Results of numerous studies (Calvo, 2001, 2004; Estévez \& Calvo, 2000; Linderholm, 2002; Singer, Andrusiak, Reisdorf, \& Black, 1992; Singer \& Ritchot, 1996) support the idea that interpersonal differences in inferential activity are determined by variables cognitive processing and therefore, this paper assumes that there is a causal relationship between the ability to remember and the inference generation, or at least there is a relative contribution of this factor.

\section{A Concrete Proposal for Educational Intervention}

After this experience, we propose here some guidelines just as a frame of reference in order that it may be the educator who sets the Program.

a) Encourage reading: reading is closely related to success in school. We should strive to develop dedicated readers, readers who are not only motivated to read for various purposes but also have the skills to understand the materials they read. Teachers can make reading more interesting and rewarding selecting 
materials using reading way that is meaningful and practical for students. They can help students develop comprehension skills.

b) Encourage the student to be an active reader: the more active the reader asking questions about what you read, relating it to what you already know, thinking about its consequences, expressing ideas in their own words, the greater your understanding of what reading and memory.

c) To teach comprehension strategies and metacognitive skills that enable the reader to use them appropriately and flexibly. These strategies are: to determine the importance of information, summarize what has been read, make inferences, and monitor autointerrogarse understanding. No doubt, as the student can master improve their reading comprehension.

We propose a specific intervention in order to prepare students for a better understanding of the text read, using a simple methodology to apply with materials easy to prepare. But we have no evidence of success, to the extent that the results are not significant, due to the study sample was not representative.

However, we think that can be a good tool to improve reading comprehension.

It remains to perform a further research that enable us to understand the process of reading comprehension and the relationship between understanding and the inferences made by the reader, and determine which tool would help better develop this understanding capacity in the process of reading any type of text.

And because of this fact, as an example, and according to the central nature of the inferences in the reading comprehension process, we developed a program to help young students to perform them, with an instrument of valuation, far from being a tedious test, is prepared to be a fun element to the student.

\begin{tabular}{|l}
\hline READING COMPREHENSION STRATEGIES \\
\hline 1. Objective: Training strategy making inferences understanding. \\
2. Participants: Students of the Language Proficiency course (old Boost Language) $2^{\text {nd }}$ \\
Secondary Education. \\
Material: We produce a booklet with sentences and paragraphs followed by questions \\
that students must answer making inferences. The texts will be of four types: \\
a) With an unknown word. \\
b) With a typo. \\
c) With one word deleted. \\
d) With difficulty syntactic. \\
It will also develop an assessment tool. \\
Procedure: Apply in the classroom during the hours of a subject like "Language \\
competence" -one hour weekly-for ten weeks. Children, with the help of the language \\
teacher, the students will have to: \\
A) Infer the meaning of an unfamiliar word: \\
$\quad$ From the context. For example: They were always small talk. They kept \\
$\quad$ talking and it went very well. \\
From the composition. For example: It was whitish. \\
From cultural knowledge. For example: Marta was awake after drinking \\
three coffees and a shower. \\
B) Infer the meaning of a word wrong or missing \\
Diving solutions to choose the right one \\
C) Inarking them important clues \\
Evaluation of results: After the training, the regulatory evaluation instrument. The form \\
of a text composed of four paragraphs in each of which appears a difficulty of those \\
worked in the training phase: the first will have an unknown word, the second one \\
wrong, the third and the fourth an empty phrase syntax complex. After reading, students \\
will have to answer questions about it. Hopefully rebel data analysis significantly \\
improved in reading comprehension from language proficiency research group's \\
students. In addition, we bet they read the text faster and manifest a greater appreciation \\
and interest in reading.
\end{tabular}


The procedure is sequenced hours per week, which facilitates its application class. And the instrument of valuation is prepared to be a fun element to the student.

In short, from the perspective of educational intervention on the issue treated in this paper, we can say that both the treatment, as programs that are normally used to treat reading difficulties, may be the same as those used to treat any delay reading process (Lyon et al., 2001).

\section{References}

Anderson, R. C., \& Pearson, P. D. (1984). A schema-theoretic view of basic processes in reading comprehension. In P. D. Pearson (Ed.), Handbook of reading research (pp. 255-291). New York: Longman.

Baker, L., \& Brown, A. L. (1984). Metacognitive skills and reading. En Pearson, P.D. Handbook of reading research (pp. 353-394). EE.UU, Longman.

Baker, L. (1991). Metacognition, Reading and science education. In Santa, \& Alverman (Eds.), En Science Learning. Newark, Delaware: IRA.

Barry, S., \& Lazarte, A. A. (1998). Evidence for mental models: How do prior knowledge, syntactic complexity, and Reading topic affect inference generation in a recall task for nonnative readers of Spanish? Modern Language Journal, 82, 176-193. http://dx.doi.org/10.1111/j.1540-4781.1998.tb01191.x

Bravo, L. (2003). Lectura inicial y psicología cognitiva. Santiago: Editorial Universidad Católica.

Brewer, W. F. (1988). Postscript: Imagery and text genre (pp. 431-438).

Brown, A. L., Campione, J. C., \& Day, J. D. (1981). Learning to learn: On training students to learn from texts. Educational Research, 10, 14-21.

Calvo, M. G. (2001). Working memory and inferences: Evidence from eye fixations during reading. Memory, 9 , 365-381. http://dx.doi.org/10.1080/09658210143000083

Calvo, M. G. (2004). Relative contribution of vocabulary knowledge and working memory span to elaborative inferences in reading. Learning and Individual Differences, 15, 53-65. http://dx.doi.org/10.1016/j.lindif.2004.07.002

Ehren, B. J. (2005). Looking for evidence-based practice in reading comprehension instruction. Topics in language disorders, 25, 4, 310-321. http://dx.doi.org/10.1097/00011363-200510000-00005

Estévez, A., \& Calvo, M. G. (2000). Working memory capacity and time course of predicive inference. Memory, 8, 51-61. http://dx.doi.org/10.1080/096582100387704

Garner, R. (1988). Metacognition and Reading Comprehension. New Jersey: Ablex Publishing Corporation.

Gagné, E. D. (1985). La Psicología Cognitiva del Aprendizaje Escolar. Madrid: Visor.

Gilabert, R., Martínez, G., \& Vidal-Abarca, E. (2005). Some good texts are always better: text revision to foster inferences of readers with high and low prior background knowledge. Learning and Instruction, 15, 45-68. http://dx.doi.org/10.1016/j.learninstruc.2004.12.003

Hall, D., \& Gathercole, S. E. (2011). Serial recall of rhythms and verbal sequences: Impacts of concurrent tasks and irrelevant sound. Quarterly Journal of Experimental Psychology, 1.

Hobbs, R. (2001). Improving reading comprehension by using media literacy activities. Voices from the Middle, $8(4), 44-50$.

Jimenez, R. P., Garcia, G. E., \& Pearson, P. D. (1996). The reading strategies of bilingual Latina/o students who are successful English readers: Opportunities and obstacles. Reading Research Quarterly, 31(1), 90-112. http://dx.doi.org/10.1598/RRQ.31.1.5

Kintsh, W. (1998). Comprehension: A Paradigm for Cognition. Cambridge: Cambridge University Press.

Kourilsky, M., \& Wittrock, M. C. (1987). Verbal and graphical strategies in teaching economics. Teaching and Teacher Education, 3(1), 1-12. http://dx.doi.org/10.1016/0742-051X(87)90030-8

Linderholm, T. (2002). Predictive inference generation as a function of working memory capacity and causal text constraints. Discourse Processes, 34, 259-280. http://dx.doi.org/10.1207/S15326950DP3403_2

Lorch Jr., R. F., \& van den Broek, P. (1997). Understanding reading comprehension: Current and future contributions of Cognitive Science. Contemporary Educational Psychology, 22, 213-246. http://dx.doi.org/10.1006/ceps.1997.0931 
Lyon, G. R., Fletcher, J. M., Shaywitz, S. E., Shaywitz, B. A., Wood, F. B., Schulte, A., \& Olson, R. (2001). Rethinking learning disabilities. In C. E. Finn Jr., R. A. J. Rotherham, \& C. R. Hokanson Jr. (Eds.), Rethinking special education for a new century. Washington, DC: Thomas B. Fordham Foundation and Progressive Police Institute.

Marmolejo-Ramos, F., de Juan, M. R. E., Gygax, P., Madden, C. J., \& Roa, S. M. (2009). Reading between the lines The activation of background knowledge during text comprehension. Pragmatics \& Cognition, 17(1), 77-107. http://dx.doi.org/10.1075/pc.17.1.03mar

Mason, L. H. (2004). Explicit self-regulated strategy development versus reciprocal questioning: Effects on expository reading comprehension among struggling readers. Journal of Educational Psychology, 96, 283-296. http://dx.doi.org/10.1037/0022-0663.96.2.283

Molinari-Marotto, C. (1998). Introducción a los modelos cognitivos de la comprensión del lenguaje. Buenos Aires: Eudeba.

Pearson, P., Roehler, L., Dole, J., \& Duffy, G. (1992). Developing Expertice Reading Comprehension. In S. J. Samuels, \& A. Farstrup (Eds.), GAT research Say About Reading Instruction (2nd ed., pp. 145-199). Newark, DE: International Readers Association.

Pino, M. M. (2002). Reconocimiento visual-ortográfico y aprendizaje de la lectura. Estudio en niños chilenos. Tesis presentada para la obtención del título de Magíster en Psicología, Pontificia Universidad Católica de Chile, Santiago, Chile.

Pressley, M., \& Wharton-Mcdonald, R. (1997). Skilled comprehension and its development through instruction. School Psycology Review, 26, 448-466.

Ryle, G. (1949). The concept of mind. Londres: Penguin Books.

Singer, M., Andrusiak, P., Reisdorf, P., \& Black, N. L. (1992). Individual differences in bridging inference processes. Memory \& Cognition, 20, 539-548. http://dx.doi.org/10.3758/BF03199586

Singer, M. Y., \& Ritchost, K. (1996). The role of working memory capacity and Knowledge acces in text inference processing. Memory \& Cognition, 24, 733-743. http://dx.doi.org/10.3758/BF03201098

Sotozaki, H., \& Hatin, B. (2011). Hemispheric processing and reading efficiency. Journal of Neurolinguistics, 24(4), 497-506. http://dx.doi.org/10.1016/j.jneuroling.2011.03.002

Storch, S., \& Whitehurst, G. (2002). Oral language and code-related precursors to reading: Evidence from a longitudinal structural model. Developmental Psychology, 38, 934-947. http://dx.doi.org/10.1037/0012-1649.38.6.934

Taboada, A., \& Guthrie, J. T. (2006). Contributions of student questioning and prior knowledge to construction of knowledge from reading information text. Journal of Literacy Research, 38(1), 1-35. http://dx.doi.org/10.1207/s15548430j1r3801_1

Tomlinson, B. (1997). The role of visualization in the reading of literature by learners of a foreign language (Unpublished PhD thesis, University of Nottingham). Microfilmed version: The British Library, British Thesis Service.

Van den Broek, P. (1994). Comprehension and memory of narrative text: Inference and coherence. In M. A. Gernsbacher (Ed.), Handbook of Psycholinguistics. San Diego, California: Academic Press.

Vargas, E., \& Arbeláez, C. (2001). Consideraciones teóricas acerca de la metacognición. Revista de Ciencias Humanas, 28. Retrieved November 21, 2012, from http://www.utp.edu.co/-chumanas/revistas/revistas/rev28/vargas.htm

Watkins, M., \& Gardiner, J. M. (1979). An appreciation of the generate-recognize theory of recall. Journal of Verbal Learning and Verbal Behavior, 18, 687-704. http://dx.doi.org/10.1016/S0022-5371(79)90397-9

Wigfield, A., Guthrie, J. T., Perencevich, K. C., Taboada, A., Klauda, S. L., Mcrae, A., \& Barbosa, P. (2008). Role of reading engagement in mediating effects of reading comprehension instruction on reading outcomes. Psychology in the Schools, 45, 432-445. http://dx.doi.org/10.1002/pits.20307

\section{Notes}

Note 1 . The mean, being a measure of central tendency provides obviously a unique value that needs to be supplemented with other data. 
Note 2. Low values of standard deviation, close to zero, we will discuss a few differences in the memory of the students, that is, they are all very close to the average. If we find high scores, average away some considerably, we have to conclude that subjects have disparate values in the variable memory.

\section{Copyrights}

Copyright for this article is retained by the author(s), with first publication rights granted to the journal.

This is an open-access article distributed under the terms and conditions of the Creative Commons Attribution license (http://creativecommons.org/licenses/by/3.0/). 